\title{
Dagu RS003B75 Chassis Mobile Robot Platform sebagai Purwarupa MINION Mobile Mines \& Intelligent Remote Detonator Robot
}

\section{Dagu RS003B75 Chassis Mobile Robot Platform as MINION Mobile Mines \& Intelligent Remote Detonator Robot}

\author{
Aditya Kurniawan ${ }^{1 *}$, Kholilatul Wardani ${ }^{2}$ \\ ${ }^{1,2}$ Politeknik Kota Malang \\ Raya Tlogowaru no 3 Malang, (0341) 745088 \\ aditya@poltekom.ac.id ${ }^{1 *}$,wardani@poltekom.ac.id ${ }^{2}$
}

\begin{abstract}
Abstrak - Dilihat dari jenis alutsista dan jumlah komponen peralatan pertahanan, Matra Darat Republik Indonesia memiliki komposisi $61 \%$ armored vehicles, $15 \%$ towed artillery, 14\% tanks, 6.5\% self-propelled guns dan sisanya adalah rocket projectors. Dilihat dari jenis alutsista yang dimiliki oleh matra darat, keseluruhanya adalah jenis alutsista yang sudah digunakan sejak jaman perang dunia kedua, sehingga untuk alutsista yang memiliki teknologi kendali jarak jauh atau otonom masih belum terlihat dalam data tersebut. Oleh karen itu pengembangan dalam alutsista jenis ini adalah hal strategis untuk dilakukan. Robot mobile kendali jarak jauh yang semi otonom MINION (Mobile mINes \& Intelligent remOte detoNator) adalah sebuah mobile robot yang dikendalikan jarak jauh dengan jaringan telekomunikasi nirkabel yang berfungsi sebagai mobile mines atau komponen alutsista berbahan peledak yang memiliki daya gempur massif. Robot mobile ini diharapkan menjadi sebuah prototipe alutsista kendali jarak jauh yang akan menambah daya gempur Angkatan Darat Republik Indonesia. Hasil dari penelitian ini diantaranya adalah sebuah prototipe mobile robot (MINION) dengan level TKT 5 dengan kesimpulan pengembangan yaitu 1) Material chassis yang digunakan untuk Minion adalah anodized aluminium yang tahan korosif berbentuk braket modular dengan tebal $2 \mathrm{~mm}, 10 \mathrm{~mm}$ pitch grid dengan lubang $4 \mathrm{~mm}$. 2) roda menggunakan material rubber dan didesain memiliki individual damper / shock absorber pada setiap roda dengan ukuran roda $120 \mathrm{~mm} \times 60 \mathrm{~mm}$ untuk meningkatkan traksi pada tanah jenis entisol dan inceptisol 3) catu daya menggunakan baterai lithium polymer 5000mAh tipe 2S 1P 20C dengan kapasitas discharge current sebesar $100 \mathrm{~A}$ yang akan di charge oleh Polycrystalline solar panel 20 wp yang mampu melakukan pengisian baterai Minion sebesar 20\% per hari.
\end{abstract}

Kata Kunci: IoT, war robot prototype, Minions, remote control.

\begin{abstract}
Judging from the type of defense equipment and the number of components of defense equipment, TNI has a composition of $61 \%$ armored vehicles, $15 \%$ towed artillery, $14 \%$ tanks, $6.5 \%$ selfpropelled guns and the rest are rocket projectors. Types of defense equipment owned by the ground forces, all of them are types of defense equipment that have been used since the era of the second world war, thus equipment that has remote control or autonomous technology is still not visible in the data. Therefore, the
\end{abstract}

TELKA, Vol.7, No.2, November 2021, pp. 120 133

ISSN (e): 2540-9123

ISSN (p): 2502-1982 
development of this type of defense equipment is strategic and crucial. The semi-autonomous remotecontrolled mobile robot MINION (Mobile Mines \& Intelligent Remote Detonator) is a remote-controlled mobile robot with a wireless telecommunications network that functions as mobile mines or components of explosive defense equipment that have massive firepower. This mobile robot is expected to become a prototype of a remote control defense system that will increase the fighting power of TNI. The results of this study include a prototype mobile robot (MINION) with TKT level 5 with development conclusions as follows 1) Chassis material used for Minion is a modular bracket corrosive resistant anodized aluminum with $2 \mathrm{~mm}$ thick, $10 \mathrm{~mm}$ pitch grid and $4 \mathrm{~mm}$ holes. 2) the wheels are rubber material and designed to have individual dampers / shock absorbers on each wheel with a wheel size of $120 \mathrm{~mm} \times 60 \mathrm{~mm}$ to increase traction on entisol and inceptisol soils 3) 5000mAh lithium polymer battery type $2 S 1 P 20 \mathrm{C}$ with discharge capacity current of $100 \mathrm{~A}$ is used for power supply system charged by a $20 \mathrm{wp}$ Polycrystalline solar panel capable of charging the Minion battery by $20 \%$ per day.

Keywords: IoT, war robot prototype, Minions, remote control

\section{Pendahuluan}

Dalam kehidupan bernegara, aspek pertahanan merupakan faktor yang sangat hakiki dalam menjamin kelangsungan hidup negara tersebut. Tanpa mampu mempertahankan diri terhadap ancaman dari luar negeri dan/atau dari dalam negeri, suatu negara tidak akan dapat mempertahankan keberadaannya [1]. Bangsa Indonesia yang memproklamasikan kemerdekaannya pada tanggal 17 Agustus 1945 bertekad bulat untuk membela, mempertahankan, dan menegakkan kemerdekaan, serta kedaulatan negara dan bangsa. Pertahanan Negara adalah segala usaha untuk mempertahankan kedaulatan negara, keutuhan wilayah Negara Kesatuan Republik Indonesia, dan keselamatan segenap bangsa dari ancaman dan gangguan terhadap keutuhan bangsa dan negara.

Dilihat dari jenis alutsista dan jumlah komponen peralatan pertahanan, Indonesia memiliki 458 pesawat tempur, dimana dari jumlah tersebut sudah termasuk 41 Fighter dan 15 Attack Helikopter. Untuk matra laut, Indonesia tercatat memiliki 282 aset, Dimana diantaranya termasuk 1 kapal perang jenis frigates, 24 jenis corvettes dan 5 kapal selam. Sedangkan untuk matra darat, militer Indonesia memiliki 332 tank, 1.430 kendaraan tempur, 153 self-propelled artillery, 366 towed artillery dan 63 rocket projectors [2]. Dilihat dari jenis alutsista yang dimiliki oleh matra darat, keseluruhanya adalah jenis alutsista yang sudah digunakan sejak jaman perang dunia kedua, sehingga untuk alutsista yang memiliki teknologi kendali atau otonom masih belum terlihat dalam data tersebut.

Dalam perkembangan teknologi Pertahanan Negara atau militer saat ini [3] [4] [5] [6] dan [7], pengembangan alutsista yang memiliki mekanisme kendali jarak jauh (drone, mobile robot dan sejenisnya) sangatlah krusial dalam menentukan kekuatan dan efisiensi daya gempur [1] [8]. Disamping memiliki akurasi yang cukup dan mengurangi korban jiwa dalam sebuah kondisi peperangan, teknologi pendukung daya gempur seperti robot kendali jarak jauh dapat menambah efisiensi dan operasional daya gempur alutsista tersebut [9]. Berdasarkan [10] [11] [12] [10] [13] dan [14], pengembangan purwarupa ini dapat dilakukan dengan menggunakan platform Dagu RS003B75 sebagai dasar chassis dan upper structure dari robot.

Tujuan penelitian yang akan dicapai adalah mengembangkan prototype mobile mines yang dapat memperkuat kualitas dan kuantitas serangan alutista angkatan darat Republik Indonesia. Manfaat penelitian yang akan dicapai adalah: 1). memberikan sumbangsih temuan berupa prototipe untuk jenis alutsista bahan peledak bergerak jarak jauh untuk matra angkatan darat Republik Indonesia, 2). menyebarkan ide ide baru dalam perkembangan jenis alutista dengan teknologi robotika dan IoT.

\section{Metode Penelitian}

Bagan alur berpikir penelitian ini dapat dilihat pada Gambar 1. 


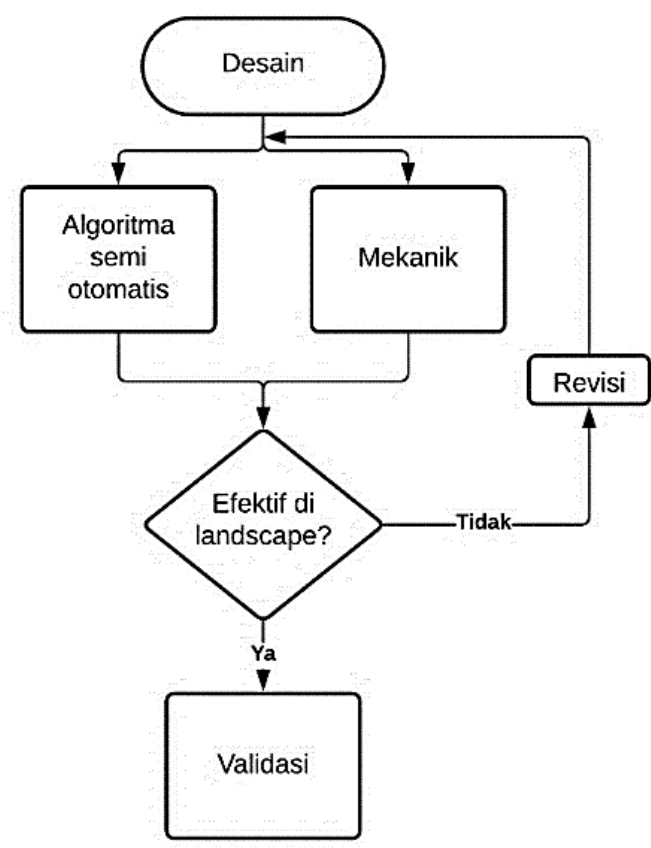

Gambar 1. Bagan metode alur penelitian.

Model pengembangan yang digunakan yaitu model Sugiyono [15] dengan langkah 1) menganalisa potensi dan masalah yang ada yaitu landscape area perang / battle ground yang menyebabkan kesulitan dalam manuver dan pergerakan Minion dan Infrastruktur yang dibutuhkan untuk mendukung operasional kendali jarak jauh Minion. 2) desain produk prototipe dan 3) validasi desain dilaksanakan melalui workshop untuk mendapatkan masukan dari ahli teknologi dan strategi perang.

\subsection{Desain prototipe Minion}

Minion (Mobile Mines \& Intelligent Remote Detonator) adalah sebuah mobile robot dengan tipe differential mobile robot atau independent mobile robot menggunakan alat gerak berupa roda. Di dalam platform dan chassis terdapat mekanisme shock absorber mini dan unit bahan peledak yang dapat dikendalikan secara jarak jauh baik arah gerak mobile robot ataupun timing peledakan bahan peledak. Gambar desain Minion dapat dilihat pada Gambar 2.
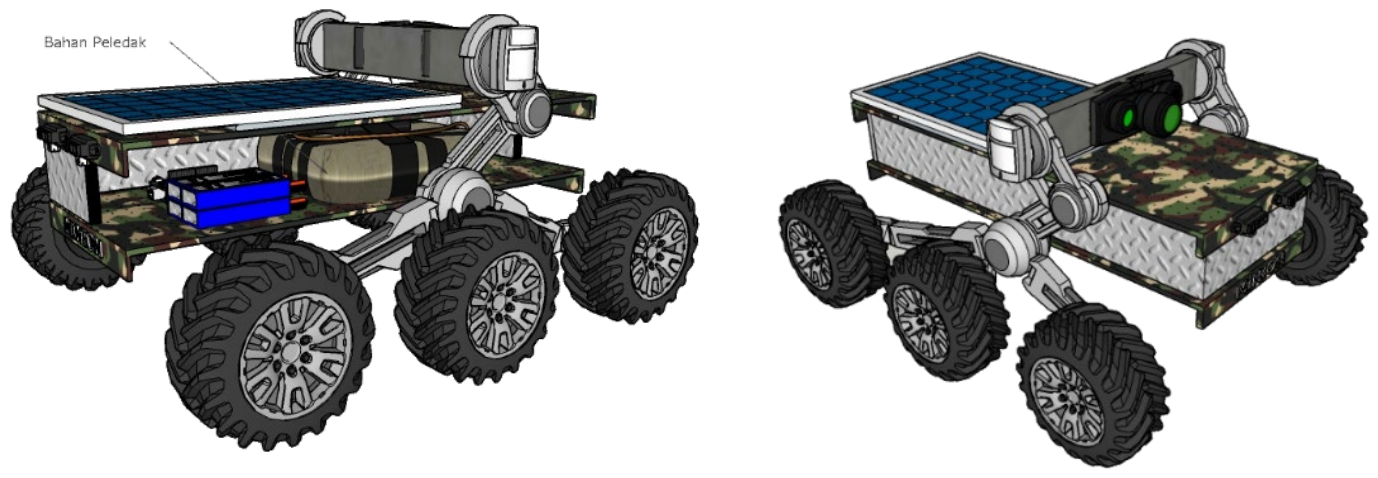

Gambar 2. Tampak bagian dalam dan isometris Minion. 
Peralatan untuk melakukan pengembangan produk ini yaitu chassis $6 W D$ wild thumper arexx JSR06 all terrain platform, 6VDC gearbox motor $75: 18.8 \mathrm{kgcm} / 131 \mathrm{rpm}$, Lithium polymer baterai $5000 \mathrm{mAh} 2 \mathrm{~S}$ 20C, driver motor BTS7960 43A dual H-bridge, Esp32 controller modul, relay module $1 \mathrm{CH}$, SIM800L modul GSM/GPRS, X14015 DC converter 75w, E18-d80nk adjustable IR sensor, GY neo6mv2 GPS modul Ublok, dan 12V colar charger 20wp.

\subsection{Aplikasi kendali Minion}

Pada sisi operator/pengendali jarak jauh Minion terdapat dua bagian kendali yaitu kendali manuver minion dan kendali detonasi bahan peledak. Aplikasi ini mengendalikan unit Minion secara jarak jauh dengan menggunakan jaringan existing GSM. Untuk lebih jelasnya dapat dilihat pada Gambar 3.

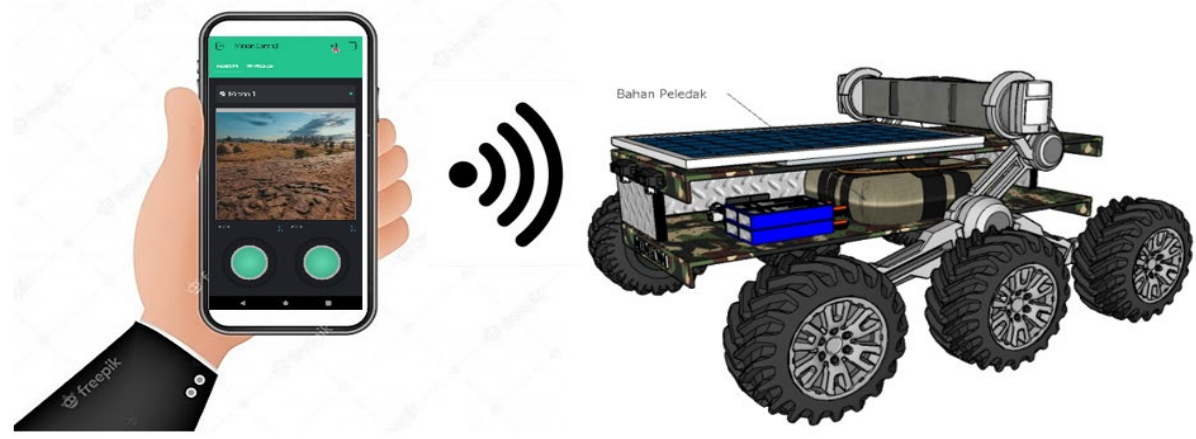

Gambar 3. Interface pada sisi operator unit Minion.

\subsection{Aplikasi kendali android berbasis platform Blynk}

Aplikasi kendali yang dikembangkan dalam penelitian ini menggunakan apps berbasis kernel linux yaitu OS android dengan platform IoT yaitu blynk. Berdasarkan [16] widget yang digunakan dalam aplikasi ini adalah map satelite view widget, device selector widget, joystick 2 axis widget, round pill button yang diseting untuk tipe switch, dan navigation tab widget yang digunakan untuk navigasi antar halaman menu. Untuk tampilan interface aplikasi android lebih jelasnya dapat dilihat pada Gambar 4 dan Gambar 5.

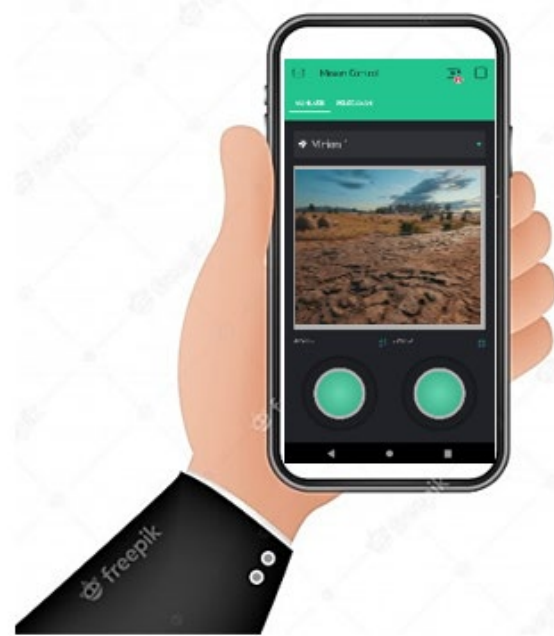

Gambar 4. Halaman kendali manuver Minion.

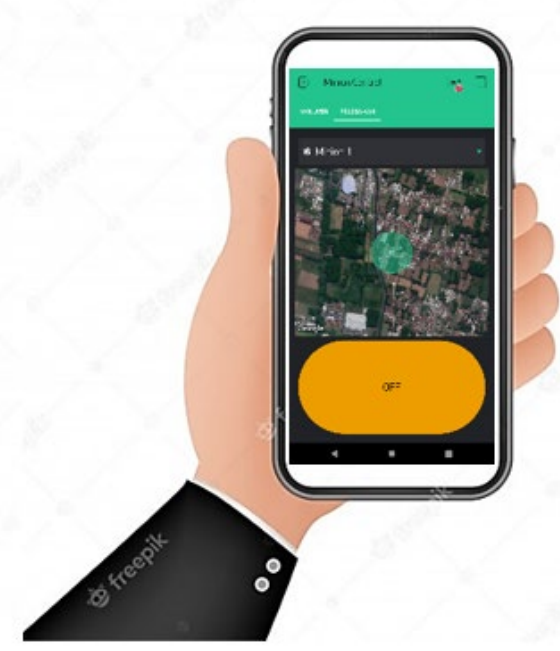

Gambar 5. Halaman kendali peledakan.

\subsection{Sistem kendali jarak jauh Mobile Mines \& Intelligent Remote Detonator}

Secara sederhana sistem ini terdiri dari 2 hal utama yaitu (1) Interface aplikasi pengendalian unit Minion dengan menggunakan aplikasi IoT yang dikembangkan seperti yang dijelaskan pada 
Gambar 4 dan Gambar 5. Kendali IoT pada unit Minion ini memungkinkan operator untuk mengendalikan manuver unit Minion yang dikendalikan oleh controller Esp32 secara penuh yaitu forward, reverse, putar kanan, putar kiri, belok kanan, dan belok kiri. (2) unit Minion yang dapat dipilih melalui device selector pada aplikasi kendali, sehingga untuk 1 interface aplikasi kendali dapat mengendalikan beberapa unit Minion yang dapat diposisikan sesuai dengan strategi penyerangan. dijelaskan pada Gambar 6.

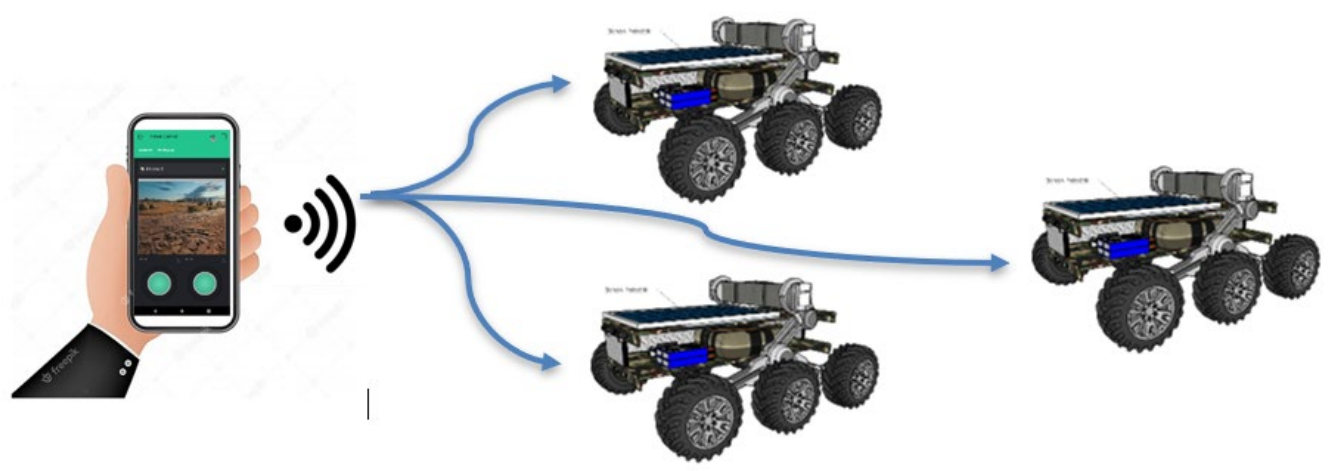

Gambar 6. Kendali multi unit dengan device selector widget.

\subsection{Perumusan masalah untuk prototipe Minion}

Masalah yang dapat muncul dalam mengoperasikan unit ini di medan pertempuran yaitu (1) jenis landscape dan gradien yang tidak rata akan berpengaruh terhadap manuver unit, (2) cuaca, air dan kelembaban akan berpengaruh pada kondisi chasis dan komponen elektronik, (3) sumber tenaga, dan (4) bandwidth yang berpengaruh terhadap kendali unit secara jarak jauh. Desain prototipe unit Minion disesuaikan dengan mempertimbangkan permasalahan di atas.

\subsection{Jenis landscape dan gradien pada battleground operasi militer di Indonesia}

Menurut [17] klasifikasi tanah dan prosentase penyebaranya dibagi menjadi entisols sebanyak $18 \%$, inceptisols sebanyak $15 \%$, aridisols sebanyak $12 \%$, alfisols sebanyak $10 \%$, gelisols sebanyak $9 \%$, ultisols sebanyak $8 \%$, oxisols sebanyak $8 \%$, mollisols sebanyak $7 \%$, spodosols sebanyak $4 \%$, vertisols sebanyak $2 \%$, andisols sebanyak $1 \%$, dan histosols sebanyak $1 \%$. Kondisi landscape entisol dapat dilihat pada Gambar 7 dan landscape inceptisol dapat dilihat pada Gambar 8. Dilihat dari prosentase sebaran jenis tanah tersebut, maka jenis dan kondisi tanah yang memiliki kemungkinan terbesar menjadi medan tempur adalah tanah dan landscape jenis entisol yang memiliki sebaran sebanyak $18 \%$ dan landscape jenis inceptisol yang memiliki sebaran sebanyak $15 \%$.

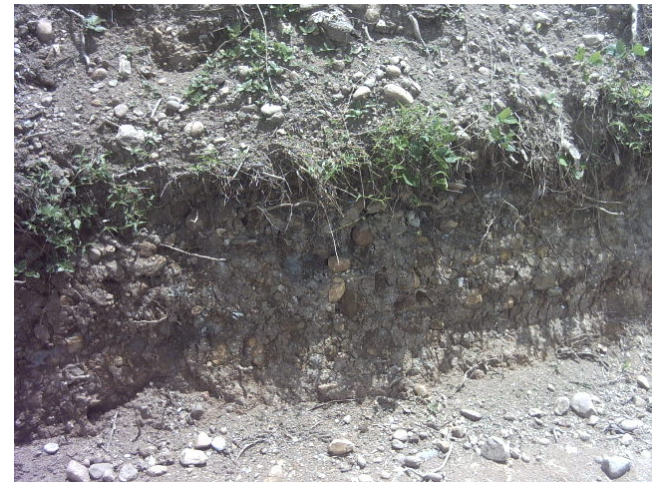

Gambar 7. Kondisi landscape entisol - 18\% permukaan bumi.

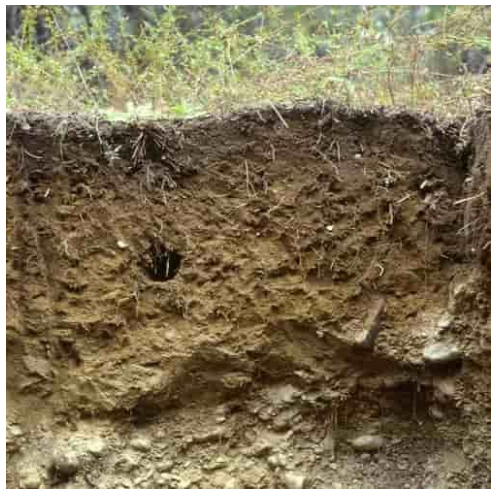

Gambar 8. Permukaan tanah landscape inceptisol $-15 \%$ permukaan bumi. 


\subsection{Kondisi cuaca pada battleground operasi militer di Indonesia}

Cuaca, curah hujan dan kelembaban di Indonesia termasuk dalam iklim tropis yang memiliki dua musim yaitu hujan dan kemarau. Kondisi yang hujan dan lembab tentunya akan menjadi permasalahan tersendiri bagi komponen elektronik di dalam unit Minion. Sesuai dengan [18] dengan mengambil contoh kota Jakarta, kondisi suhu sepanjang tahun di Indonesia dapat dilihat pada Gambar 9, sedangkan grafik kelembaban pada Gambar 10, dan curah hujan pada Gambar 11.

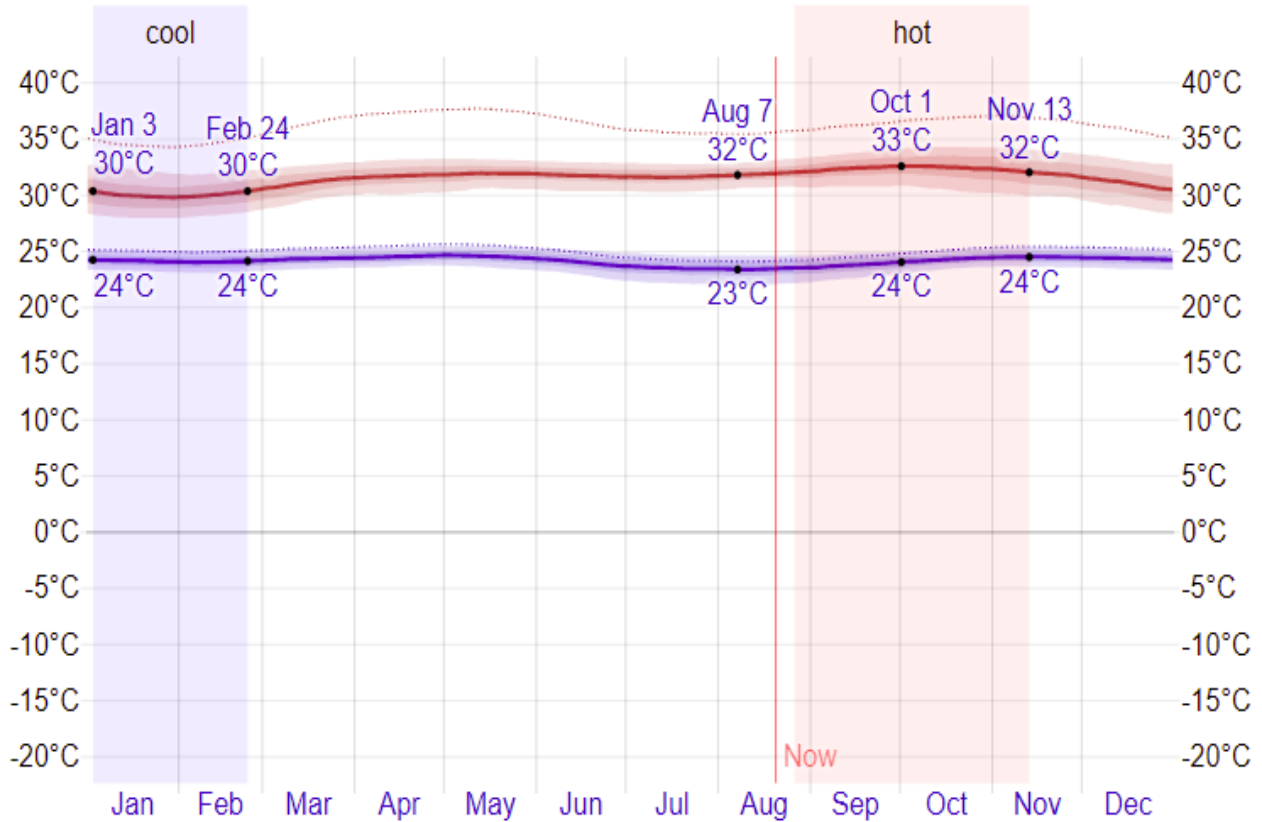

Gambar 9. grafik suhu di Indonesia.

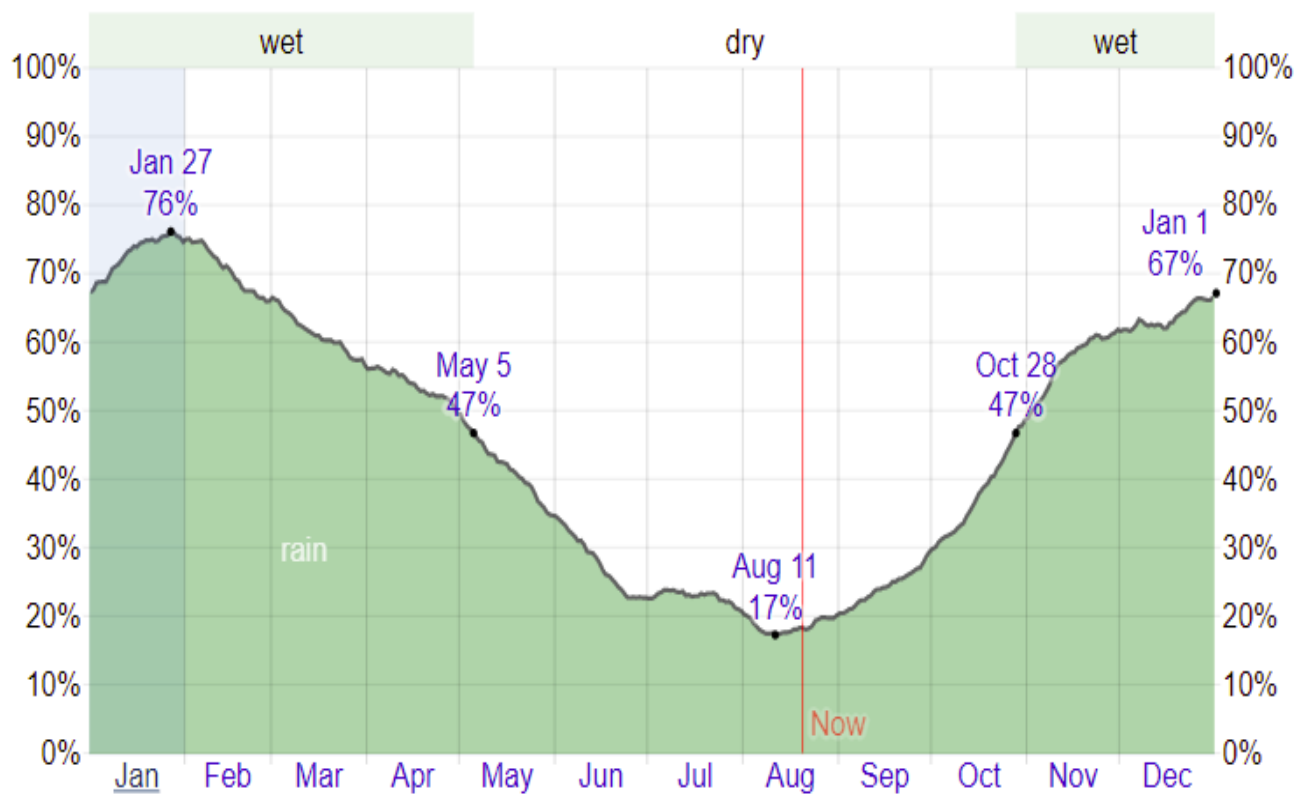

Gambar 10. grafik kelembaban di Indonesia. 


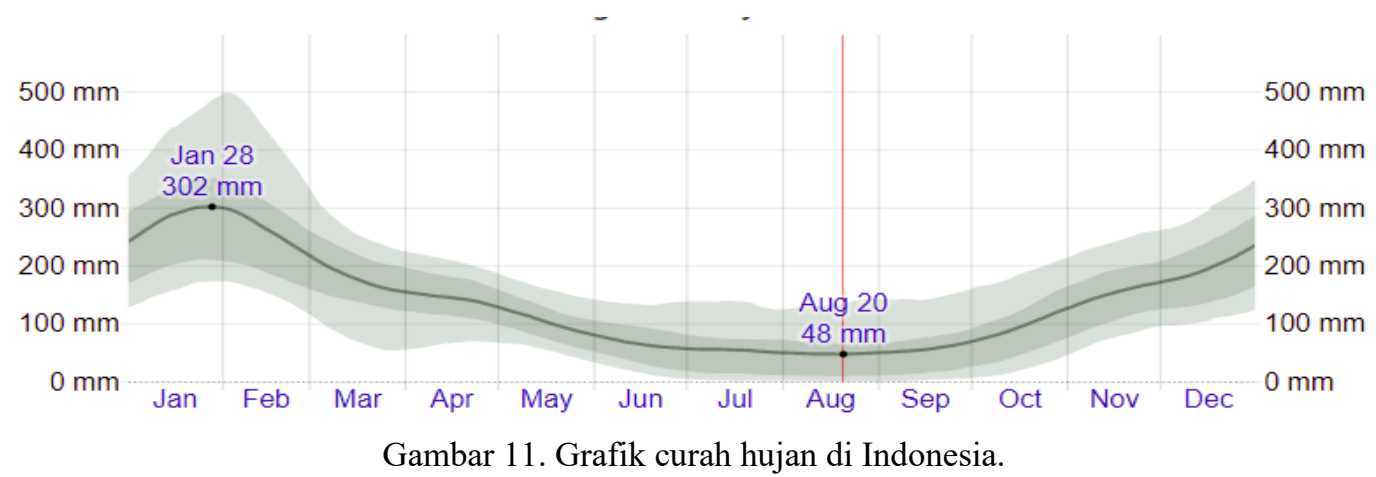

Sumber tenaga yang dibutuhkan oleh unit minion tergantung pada waktu yang digunakan saat unit bermanuver dan kondisi landscape saat unit beroperasi. Semakin tidak rata landscape, maka konsumsi energi akan semakin besar. Unit minion didesain untuk melakukan self charging dengan memanfaatkan energi matahari / solar energy. Menurut [18] Solar energy di Indonesia sepanjang tahun dapat dilihat pada Gambar 12.

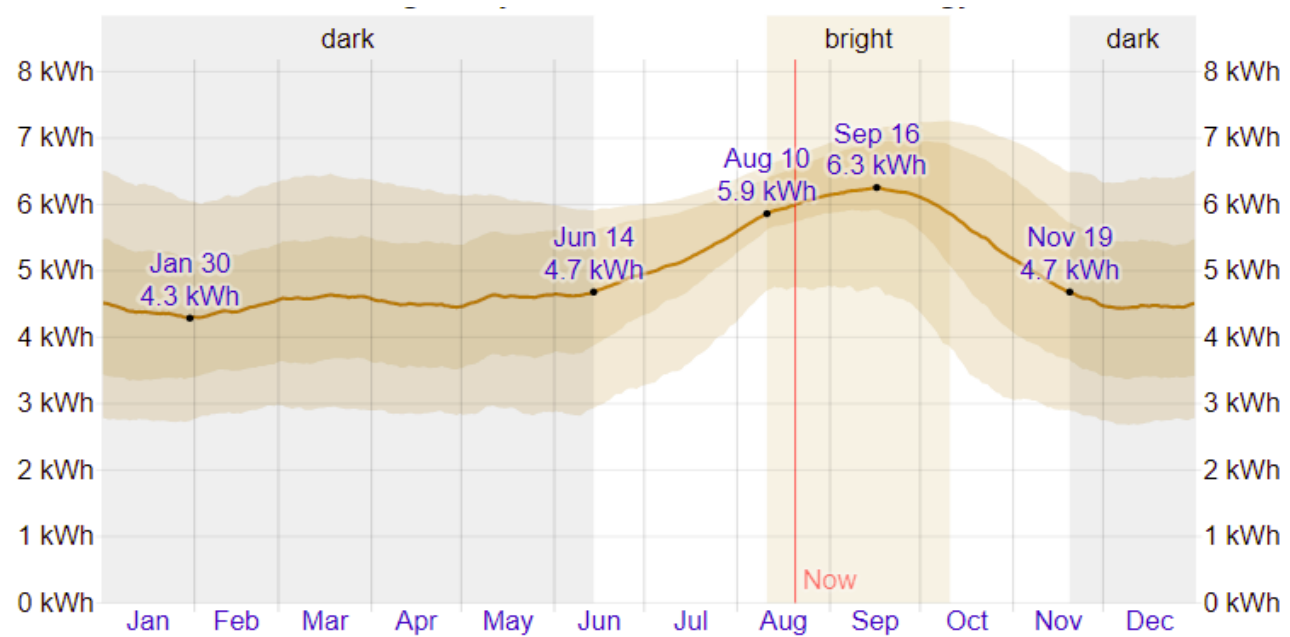

Gambar 12. Grafik energi matahari sepanjang tahun di Indonesia.

Sedangkan kondisi bandwidth di Indonesia dapat dilihat pada data menurut [19] pada Gambar 14 dibandingkan dengan bandwidth secara global pada Gambar 13. Bandwidth akan digunakan sebagai media komunikasi data antara unit Minion dan aplikasi kendali.



Gambar 13. Bandwidth rata rata global.

Gambar 14. Bandwidth rata rata Indonesia. 


\subsection{Analisis kondisi battleground operasi militer di Indonesia}

Pada tahap pengumpulan data, informasi yang sudah diperoleh akan dianalisis sebagai bahan perencanaan desain unit Minion. Analisis data meliputi: 1) analisis kondisi landscape secara garis besar di Indonesia, 2) analisis cuaca, air dan kelembaban rata rata di Indonesia, 3) analisis ketersediaan sumber tenaga matahari, dan 4) analisis bandwidth dengan jaringan mobile di Indonesia dan 5) analisis infrastruktur jaringan GSM.

\subsection{Analisa kondisi jenis tanah di Indonesia}

Kondisi jenis tanah yang ada berdasarkan [17] yang paling besar adalah jenis entisol dan inceptisol yaitu sebesar 33\% permukaan bumi di Indonesia. Dari Gambar 7 dan 8 dapat disimpulkan kondisi landscape tersebut tidak rata, dan memiliki butiran kasar pada permukaanya. Butiran tersebut memiliki kemungkinan untuk membuat unit Minion selip dan landscape dapat membuat unit terguling saat beroperasi pada bagian slope yang curam dan tajam. Dengan memperhatikan ukuran butiran tanah pada Tabel 1, maka dibutuhkan sebuah roda penggerak yang dapat melewati butiran dengan tipe halus, sedang dan kasar yang terdapat pada tanah jenis entisol dan inceptisol.

Tabel 1. Tipe ukuran butiran dan struktur tanah (dalam $\mathrm{mm}$ ).

\begin{tabular}{lccc}
\hline Ukuran Kelas & Granular platy & Columnar prismatic & Angular, subangular blocky \\
\hline Sangat halus & $<1$ & $<10$ & $<5$ \\
Halus & $1-2$ & $10-20$ & $5-10$ \\
Sedang & $2-5$ & $20-50$ & $10-20$ \\
Kasar & $5-10$ & $50-100$ & $20-50$ \\
Sangat kasar & $>10$ & $100-500$ & $>50$ \\
Paling kasar & - & 500 & - \\
\hline
\end{tabular}

\subsection{Analisa curah hujan di Indonesia}

Curah hujan yang dilihat pada Gambar 11 menunjukan bahwa curah hujan tertinggi terdapat pada bulan januari dan februari yaitu sebanyak $500 \mathrm{~mm}$ dengan rata rata pada rentang bulan itu yaitu $302 \mathrm{~mm}$. Curah hujan dalam $\mathrm{mm}$ adalah ketinggian air hujan yang terkumpul dalam penakar hujan pada tempat yang datar, tidak menyerap, tidak meresap dan tidak mengalir. Unsur hujan 1 (satu) milimeter artinya dalam luasan satu meter persegi pada tempat yang datar tertampung air hujan setinggi satu milimeter atau tertampung air hujan sebanyak satu liter. Dengan demikian pada bulan januari dan februari terdapat potensi air sebanyak 500 liter pada area 1 meter persegi dengan rata rata 302 liter dalam area 1 meter persegi.

\subsection{Analisa kuantitas energi matahari di Indonesia}

Energi matahari menurut [18] sesuai dengan Gambar 12 menunjukan bahwa energi matahari yang dapat dikonversi menjadi listrik secara rata rata sepanjang tahun di Indonesia yaitu 1) masa lebih cerah (energi paling tinggi) dalam setahun berlangsung selama 2 bulan, dari 31 Agustus sampai 9 November, dengan momen energi gelombang pendek harian rata-rata per meter persegi di atas $6.8 \mathrm{kWh}$. Hari paling cerah sepanjang tahun adalah 14 Oktober, dengan rata-rata energi matahari sebesar $7.3 \mathrm{kWh}$ 2) masa lebih gelap (energi rendah) dalam setahun berlangsung selama 3 bulan, dari 10 Desember sampai 18 Maret, dengan momen energi gelombang pendek harian rata-rata per meter persegi di bawah 5,3 kWh. Hari tergelap sepanjang tahun adalah 3 Februari, dengan rata-rata $4.8 \mathrm{kWh}$.

\subsection{Analisa bandwidth dan infrastuktur telekomunikasi di Indonesia}

Bandwidth di Indonesia menurut [19] dan [20] memiliki urutan ke 10 dengan kecepatan downlink rata rata untuk jaringan mobile adalah 21.35 Mbps dan uplink 12.29 Mbps yang bervariasi pada setiap jaringan mobile tergantung provider jaringan tersebut. Mengacu pada [19] kecepatan downlink paling tinggi adalah provider Telkomsel dengan kecepatan 13.4 Mbps dan uplink dengan kecepatan 6.8 Mbps. Grafik uplink dan downlink dapat dilihat pada Gambar 15. 


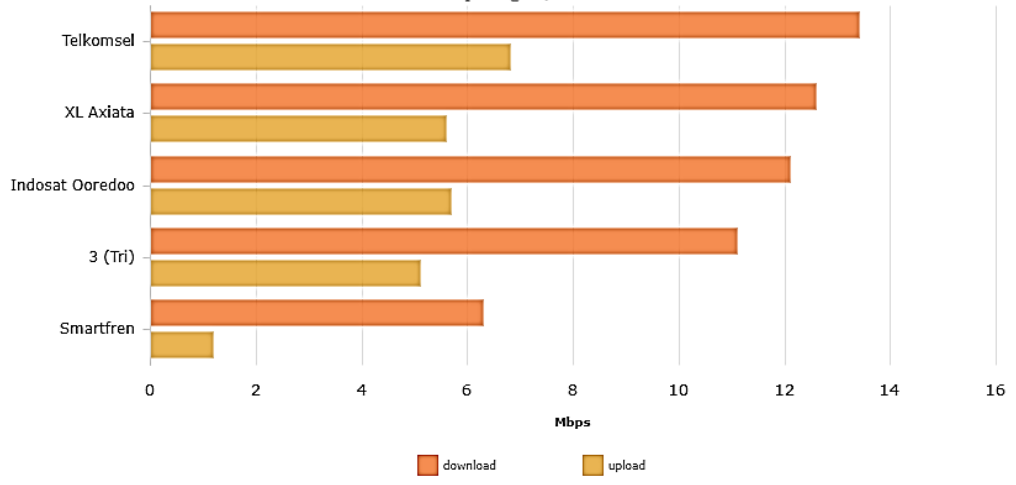

Gambar 15. Grafik uplink dan downlink pada beberapa provider jaringan mobile.

Berdasarkan [21], cakupan jaringan untuk beberapa provider jaringan yang ada di Indonesia dapat dilihat pada Gambar $16-20$.

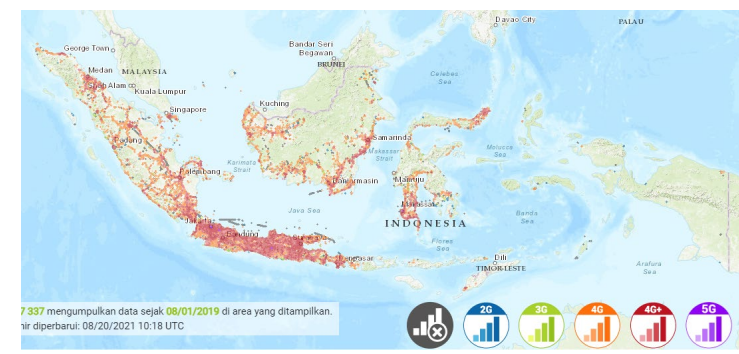

Gambar 16. Cakupan jaringan Indosat Ooredo.

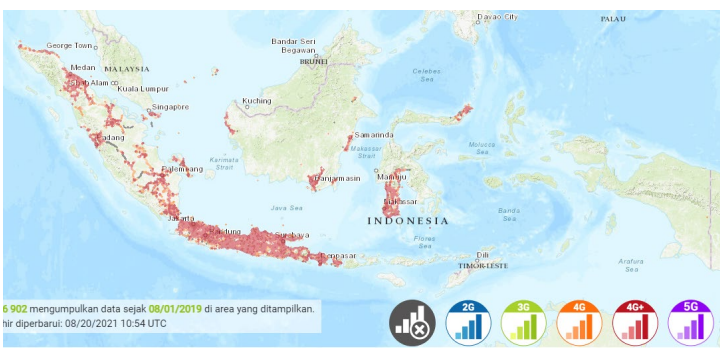

Gambar 18. Cakupan jaringan Smartfren.

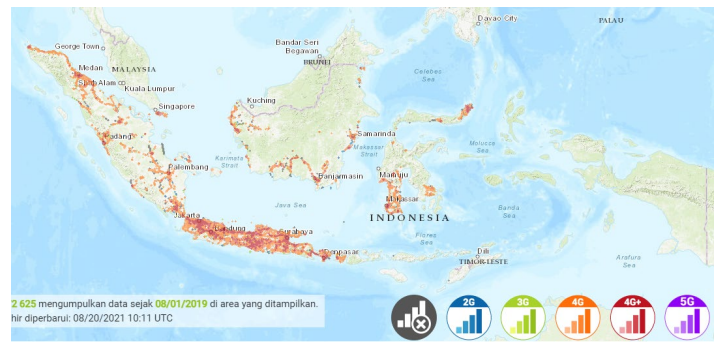

Gambar 17. Cakupan jaringan Tri.

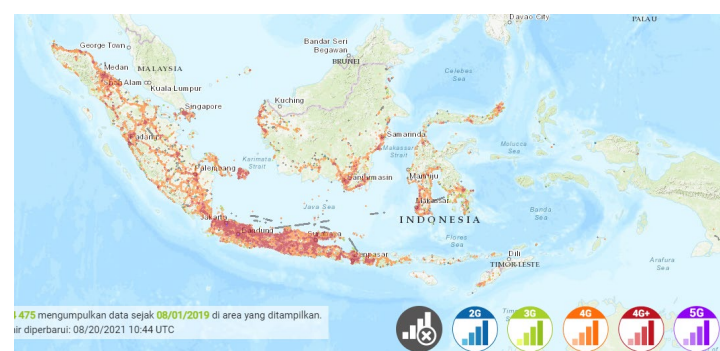

Gambar 19. Cakupan jaringan XL axiata.

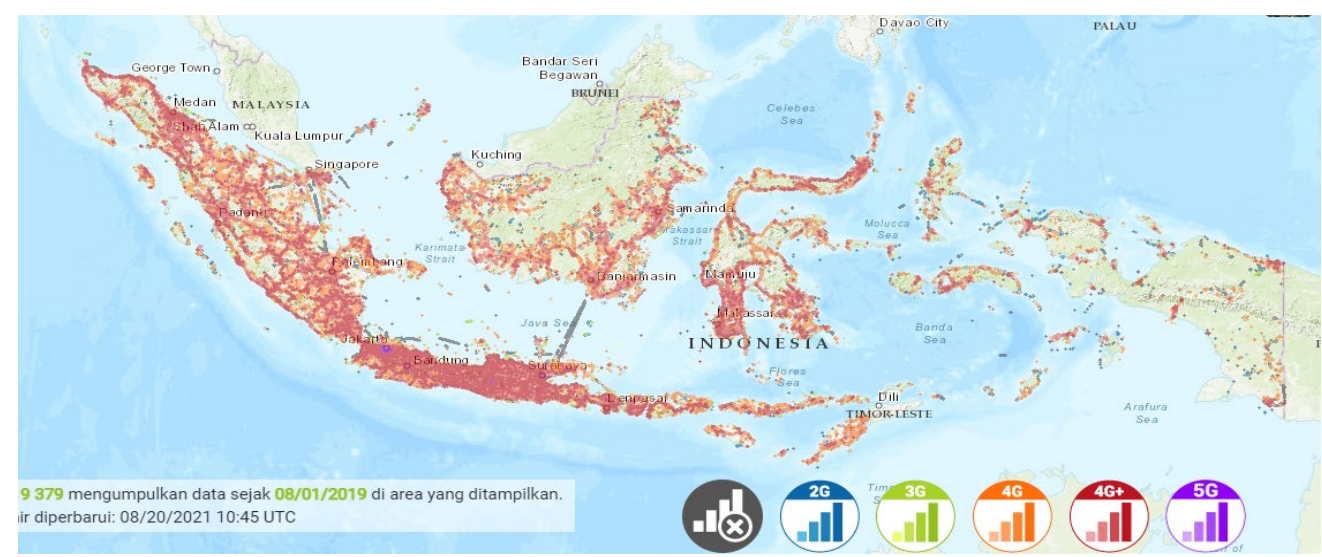

Gambar 20. Cakupan jaringan Telkomsel. 
Dari Gambar 16-20 dapat dilihat bahwa cakupan jaringan yang terluas adalah provider Telkomsel, dengan cakupan mayoritas jaringan $4 \mathrm{G}$ dan $4 \mathrm{G}+$.

\section{Hasil dan Pembahasan}

Berdasarkan data kondisi landscape, cuaca, energi matahari, dan bandwidth, maka produk yang pengembangan unit Minion Mobile Mines \& Intelligent Remote Detonator mencakup 1). desain chassis dan wheel, 2). perangkat elektronik, 3). desain sistem pengisian tenaga Minion, dan 4). desain perangkat lunak android sebagai pengendali terpusat berbasis IoT.

\subsection{Chassis \& wheel Minion}

Dikarenakan kondisi tanah jenis entisol dan inceptisol yaitu sebesar 33\% dengan granular platy $5-10 \mathrm{~mm}$, dan curah hujan rata rata sebesar $302 \mathrm{~mm}$ maka unit chassis minion didesain dengan sistem modular berupa braket yang membentuk struktur tubuh minion untuk memudahkan part replacement jika terjadi korosif dan deformasi akibat benturan. Chassis ini dikembangkan berdasarkan chassis robot dagu all terrain chassis 6WD yang terdiri dari: pertama, anodized aluminium yang tahan korosif berbentuk braket modular dengan tebal $2 \mathrm{~mm}, 10 \mathrm{~mm}$ pitch grid dengan lubang 4mm. Desain chassis dapat dilihat pada Gambar 21 dan Gambar 22.
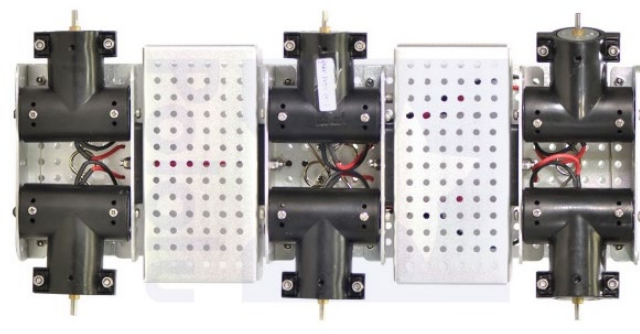

Gambar 21. Chassis Minion tampak bawah.



Gambar 22. Chassis Minion tampak samping.

Kedua, motor DC gearbox $11 \mathrm{kgcm} 160 \mathrm{rpm}$ dengan stall current $6.6 \mathrm{~A}$, ketiga, individual damper/shock absorber pada setiap roda, dan keempat, roda $120 \mathrm{~mm}$ x $60 \mathrm{~mm}$ rubber dengan sharp point untuk meninkatkan traksi pada tanah jenis entisol dan inceptisol. Model wheel dapat dilihat pada Gambar 23.

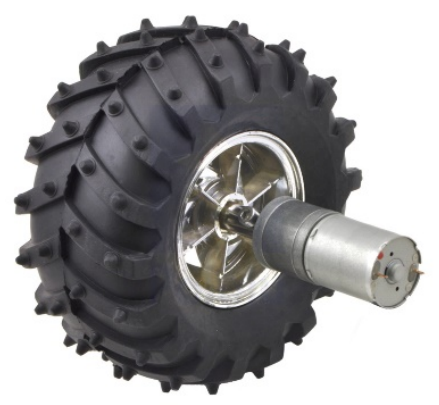

Gambar 23. Roda Minion rubber 120 x 60 .

\subsection{Perangkat elektronik Minion}

Perangkat elektronik Minion terdiri dari bagian sensor, kendali dan power supply. Untuk bagian sensor, Minion menggunakan (1) sensor GPS GY6MV2 (2) E18-d80nk adjustable IR sensor. Sensor GPS memiliki spesifikasi yaitu tegangan kerja $3 \mathrm{~V}$ sampai $5 \mathrm{~V}$, kode model: GYGPS6MV2, tipe antena keramik, memori EEPROM, backup battery, LED signal indicator, kecepatan komunikasi 9600 bps, ukuran modul $23 \mathrm{~mm}$ x $30 \mathrm{~mm}$, dan ukuran antena $12 \mathrm{~mm}$ x 12 $\mathrm{mm}$. Skematik modul ini dapat dilihat pada Gambar 24, sedangkan wiring diagram komunikasi GPS modul dengan kontroler mikro dapat dilihat pada Gambar 25. 


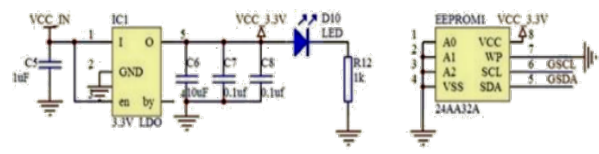

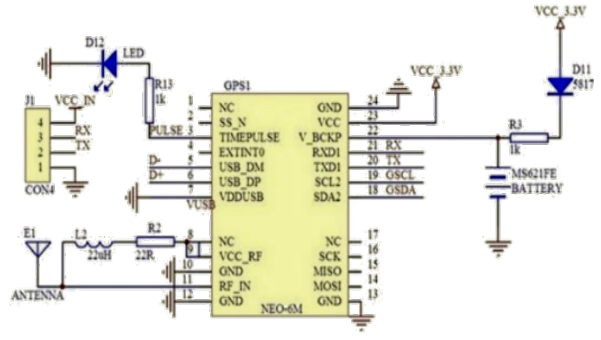

Gambar 24. Skematik diagram GPS6MV2.

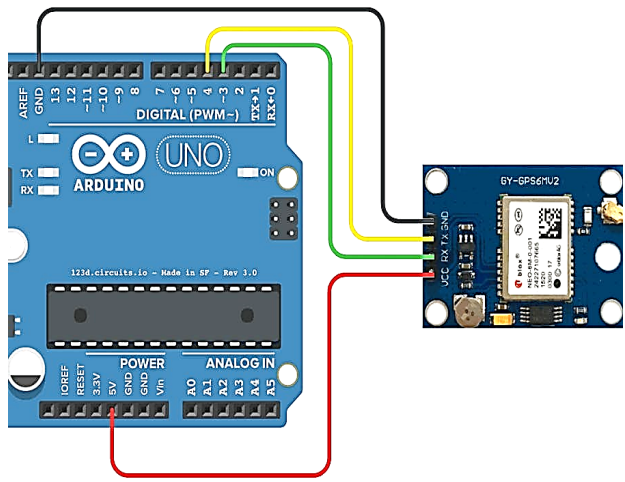

Gambar 25. Wiring diagram GPS6MV2.

Perangkat sensor selanjutnya adalah E18-d80nk adjustable IR sensor yang berfungsi sebagai sensor deteksi halangan sehingga Minion secara semi otomatis dapat menghindari obstacle saat bermanuver tanpa harus dikendalikan oleh operator. Mekanisme ini akan didukung oleh algoritma obstacle avoidance yang di letakan pada modul kendali yaitu ESP32. Sensor ini memiliki spesifikasi yaitu tegangan masukan 5V DC, konsumsi arus $>25 \mathrm{~mA}$ (minimum) - 100mA (maksimum), ukuran sensor $17 \mathrm{~mm}$ (diameter) x $45 \mathrm{~mm}$ (panjang), tipe deteksi objek transparan atau opaque, jarak deteksi sensor $30 \mathrm{~mm}-800 \mathrm{~mm}$ tergantung dengan permukaan objek, NPN output (normally high) atau berlogika true $(\mathrm{ON})$ saat aktif. Wiring diagram untuk sensor ini dapat dilihat pada Gambar 26.



Gambar 26. Wiring diagram sensor E18-d80nk.

\subsection{Perangkat elektronik Minion}

Power supply yang digunakan terdiri dari (1) baterai lithium polymer 5000mAh dengan tipe 2S 1P 20C yang memiliki level tegangan 7.4V dan kapasitas discharge current sebesar 100A dalam satu waktu (2) chip Xl4015 DC converter 5A 75w (3) Polycrystalline solar panel 20wp dengan tegangan maksimum (Vmp): $17.8 \mathrm{~V}$ dan maksimum arus pengisian (Imp) : 1.13A. Diagram skematik rangkaian distribusi tenaga pada minion dapat dilihat pada Gambar 27. Dengan momen energi gelombang pendek harian rata-rata per meter persegi di Indonesia sebesar 5,18 $\mathrm{kWh}$ konfigurasi ini akan menghasilkan arus pengisian efektif saat siang hari sebesar $0.25 \mathrm{~A}$ selama 3-4 jam. 


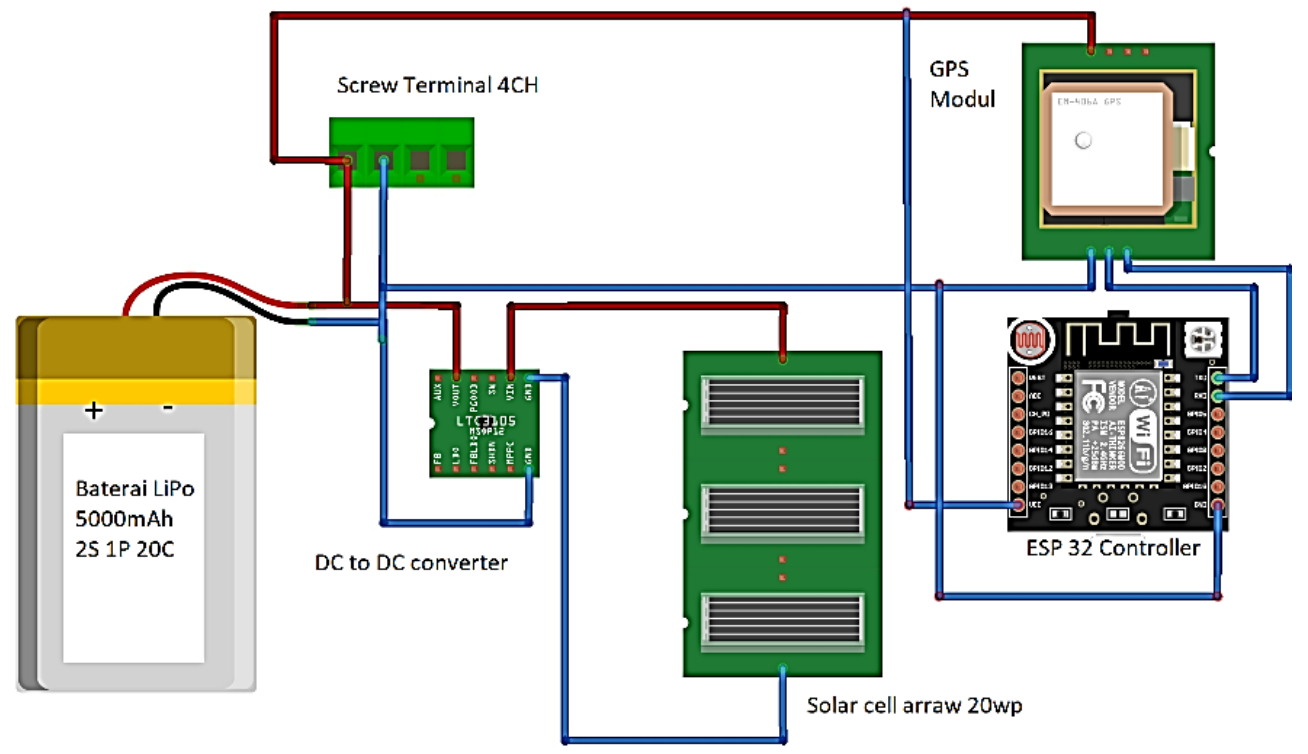

Gambar 27. Diagram rangkaian distribusi tenaga.

\subsection{Perangkat elektronik Minion}

Perangkat lunak android ini dibuat dengan compiler blynk dan dapat dimanfaatkan dengan cara scan $Q R$ code akses untuk aplikasi yang dikembangkan dalam penelitian ini. Screen capture interface dapat dilihat pada Gambar 28 dan Gambar 29.

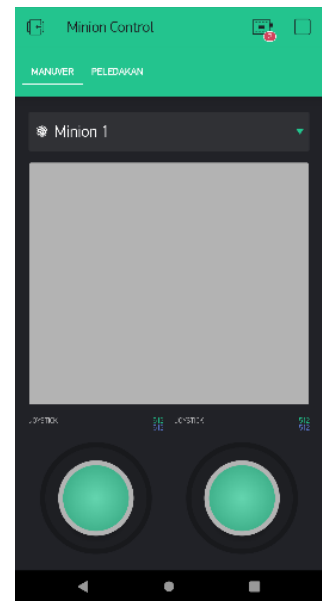

Gambar 28. Halaman kendali Minion.

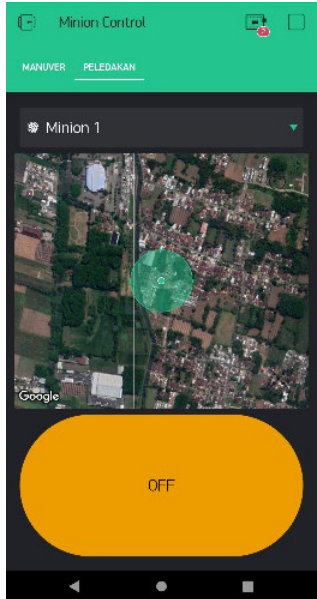

Gambar 29. Halaman kendali bahan peledak.

\section{Kesimpulan}

Hasil pengembangan desain prototipe Minion dapat disimpulkan menjadi 1). Material chassis yang digunakan untuk Minion adalah anodized aluminium yang tahan korosif berbentuk braket modular dengan tebal $2 \mathrm{~mm}, 10 \mathrm{~mm}$ pitch grid dengan lubang $4 \mathrm{~mm}, 2)$. roda menggunakan material rubber dan didesain memiliki individual damper/shock absorber pada setiap roda dengan ukuran roda $120 \mathrm{~mm}$ x $60 \mathrm{~mm}$ untuk meningkatkan traksi pada tanah jenis entisol dan inceptisol, dan 3). catu daya menggunakan baterai lithium polymer 5000mAh tipe $2 \mathrm{~S} 1 \mathrm{P} 20 \mathrm{C}$ dengan kapasitas discharge current sebesar 100A yang akan di charge oleh Polycrystalline solar panel $20 \mathrm{wp}$ yang mampu melakukan pengisian baterai Minion sebesar $20 \%$ per hari. 


\section{Referensi}

[1] S. L. L. N, S. J dan A. T, Modernization of the main weaponry system of the Indonesian Armed Forces to build strong Indonesia, Jakarta: Public Communication Center of the Ministry of Defense, 2014.

[2] "Military strength," Global fire power, 2021. [Online]. Available: https://www.globalfirepower.com/country-military-strengthdetail.php?country_id=indonesia. [Diakses 30 Juli 2021].

[3] A. Raharjo, K. Eko dan A. Imam, "Rancang Bangun Tracking Arah Tembakan Menggunakan Sensor Posisi Berbasis PID Design and Implementation of the Shot Direction Tracking System Using a PID-Based Position Sensor," TELKA-Jurnal Telekomunikasi, Elektronika, Komputasi dan Kontrol, vol. 7, no. 1, pp. 43-48, 2021.

[4] F. Triantama, "Kerjasama Pengembangan Medium Battle Tank Harimau Sebagai Perwujudan Ketahanan Alutsista Tentara Nasional Indonesia," Jurnal Ketahanan Nasional, vol. 26, no. 2, pp. 273-392, 2020.

[5] H. Kristian, "Pemodelan Dan Rancang Bangun Sistem Pengendalian Pid Dan Sliding Mode Control Untuk Remote Control Weapon Station (Rcws)," Diss. Institut Teknologi Sepuluh Nopember, 2017.

[6] I. F. Mhd, "Rancang Bangun Sistem Kendali Robot Tank Berbasis Internet of Things (IoT)," Jurnal Telkommil, vol. 1, pp. 1-7, 2020.

[7] Soerjono, T. Helmi, N. A. Muhamad dan A. N. Soni, "Perkembangan Alutsista Satuan Infanteri Pada Prioritas Pembangunan Minimum Essential Force (Mef)," Jurnal Kolaborasi Resolusi Konflik, vol. 1, no. 1, pp. 17-27, 2019.

[8] M. M dan H. A, Kajian kebijakan alutsista pertahanan dan keamanan Republik Indonesia, Jakarta: Lipi Press, 2013.

[9] N. V dan L. S, Autonomous Military Robotics, Springer International Publishing, 2014.

[10] A. Kurniawan dan K. Wardani, "Kinect Structural Noise Elimination Technique For ITIS Mobile Robot Data Collector," International Journal Of Engineering \& Technology, vol. 7, no. 4.27, 2018.

[11] A. Kurniawan dan W. Kholilatul, "Saturated Iteration of Neighbor-hood Averaging Filter Algorithm For Kinect Structural Noise Eliminator For Wild Thumper," KINETIK-Game Technology Information System Computer Network Computing, Electronics and Control, vol. 3, 2018.

[12] A. Kurniawan dan W. Kholilatul, "Pengaruh Isolated Neighborhood-Averaging Filters Pada Kinect Structural Noise Sebagai Sistem Navigasi Robot Wild Thumper," TELKAJurnal Telekomunikasi, Elektronika, Komputasi dan Kontrol, vol. 3, no. 1, pp. 49-56, 2017.

[13] A. Kurniawan, E. Mulyana dan K. Wardani, "Image Based Centre Object Calculation Using Coordinate Averaging Method For Object Following Mobile Robot.," dalam 2nd International Conference of Intelligent Robotic and Control Engineering (IRCE), Yogyakarta, 2019.

[14] A. Kurniawan dan W. Kholilatul, "Kinect Structural Noise Elimination Technique For ITIS Mobile Robot Data Collector," International Journal of Engineering \& Technology, vol. 7, no. 4.27, pp. 1-5, 2018.

[15] Sugiyono, Metode Penelitian Kuantitatif Kualitatif dan R\&D, Bandung: Alfabeta, 2011.

[16] "Introduction : Blynk Documentation," Blynk, 2021. [Online]. Available: https://docs.blynk.io/en/. [Diakses 9 Mei 2021].

[17] D. Fiantis, Morfologi dan Klasifikasi Tanah, Lembaga Pengembangan Teknologi Informasi dan Komunikasi Universitas Andalas, 2017. 
[18] "weatherspark," Cedar Lake Ventures Inc, [Online]. Available: https://weatherspark.com/y/116847/Average-Weather-in-Jakarta-Indonesia-Year-Round. [Diakses 20 Agustus 2021].

[19] "Speedtest," Ookla, [Online]. Available: https://www.speedtest.net/global-index. [Diakses 20 Agustus 2021].

[20] "Mobile Network Experience Report Indonesia June 2021," OpenSignal, 2021. [Online]. Available: https://www.opensignal.com/reports/2021/06/indonesia/mobile-networkexperience. [Diakses 20 Agustus 2021].

[21] “cdn nperf," nperf, 2014. [Online]. Available: https://cdn.nperf.com/id/map/ID/-//signal/?11=-2.5678942164342513\&lg=118.01999999999998\&zoom=5. [Diakses 20 Agustus 2021]. 